\title{
GOVERNANCE DI LINGKUNGAN USAHA KECIL MENENGAH STUDI EMPIRIS PADA USAHA KECIL MENENGAH DI PROPINSI DIY
}

\author{
Audita Nuvriasari \\ Uning Hadiyati \\ Universitas Mercu Buana Yogyakarta
}

\begin{abstract}
This study examines the implementation of good governance in Small Medium Sized Enterprises (SMEs). The specific purposes of this study are to analyzing: (1) the implementation of governance's perspective: structure, mechanism, legal framework, regulations and business environment, (2) the perception of stakeholders (financial institutions) to the implementation of corporate governance in SMEs, (3) the differences of governance's implementation in small business and medium business, (4) the differences of SMEs performance and (5) the relationship between corporate governance and firm performance.

A sample of 60 SMEs and 10 financial institutions as stakeholders was used in this study. The tools that used in this study are: statistic descriptive, quartile, significant mean differences between two groups, regression and correlations. From this study can be concluded that the implementation of good corporate governance in SMEs are poor (score 0.3798 less than 0.50). Only 15\% SMEs implementing corporate governance in good level and $85 \%$ in poor level. From statistic descriptive can be shown that the implementation of governance structure which consists of organizational structure and internal business process is weak to support the good corporate governance in SMEs. The governance mechanism which consists of corporate strategy, corporate policy and standard operating procedure can support the implementation of good corporate governance in SMEs. External forces including government regulation, business environment and legal framework is weak to support the implementation of good corporate governance in SMEs. From the comparison can be shown that there is no difference between the implementation of corporate governance in Small and Medium business. The business performance between Small and Medium business is different and there is a positive correlation between corporate governance and firm performance.
\end{abstract}

Keywords: Small Medium Sized Enterprises, Good Corporate Governance, governance structure, governance mechanism, external forces

\section{PENDAHULUAN}

Keberadaan perusahaan skala usaha kecil dan menengah (UKM) memberikan peranan penting dalam menyumbang perekonomian nasional terutama dalam kontribusi pembentukan Produk Domestik Bruto (PDB) dan penyerapan tenaga kerja. Pada tahun 2006, UKM mampu menyerap tenaga kerja sebesar 85.416 .493 orang atau $96,18 \%$ dari total penyerapan tenaga kerja yang ada, jumlah ini meningkat sebesar $2,62 \%$ atau 2.182.700 orang dibandingkan tahun 2005 . Kontribusi usaha kecil tercatat sebanyak 80.933.384 orang atau $91,14 \%$ dan usaha menengah sebanyak 4.483 .109 orang atau $5,05 \%$. Perkembangan jumlah UKM periode 2005-2006 mengalami peningkatan sebesar $3,88 \%$ yaitu dari 47.102 .744 unit pada tahun 2005 menjadi 48.929 .636 unit pada tahun 2006. Sedangkan pada tahun 2006, peran 
UMKM terhadap penciptaan PDB nasional menurut harga berlaku tercatat sebesar Rp. $1.778,75$ triliun atau $53,28 \%$ dari total PDB nasional, mengalami perkembangan sebesar Rp. 287,68 triliun atau 19,29\% dibanding tahun 2005. Kontribusi usaha kecil tercatat sebesar Rp. 1.257,65 triliun atau 37,67\% dan usaha menengah sebesar Rp. 521,09 triliun atau $15,61 \%$, selebihnya sebesar Rp. $1.559,45$ triliun atau $46,72 \%$ merupakan kontribusi usaha besar (BPS dan Kementrian Koperasi dan UKM, 2007).

Eksistensi UKM pada kondisi krisis yang melanda Indonesia dan negara di Asia lainnya mampu membuktikan bahwa UKM lebih dapat bertahan dibanding Usaha Besar dikarenakan pelaksanaan usahanya lebih efisien dan produktif dan UKM merupakan bentuk ekonomi kerakyatan dengan skala usaha yang dinamis, artinya mempunyai daya responsif, fleksibel dan adaptasi yang tinggi terhadap pesatnya perubahan kondisi eksternal, namun demikian sektor ini masih terkendala dalam upaya meningkatkan daya saing (competitiveness).

Berbagai kendala yang sering dihadapi kelompok UKM diantaranya adalah 40,34\% dari jumlah pengusaha menghadapi kesulitan permodalan, $41,9 \%$ kesulitan bahan baku, 29,9\% kesulitan pemasaran dan kesulitan membayar pekerja $18,1 \%$ (Tambunan, 2002). Hasil riset menyebutkan bahwa salah satu hambatan utama yang dihadapi UKM berkenaan dengan aspek permodalan atau pembiayaan (Bisnis Indonesia, 2002). Sementara untuk mengakses permodalan sektor UKM menemui hambatan teknis, diantaranya adalah persyaratan tentang agunan (jaminan kredit). Penyaluran kredit pada UKM dengan menyertakan persyaratan teknis jelas akan menimbulkan masalah bagi UKM karena pada umumnya memiliki manajemen usaha yang lemah. Karakteristik lain yang umumnya melekat pada UKM adalah pengelolaan perusahaan yang masih tradisional, menggunakan sistem keuangan sederhana, minimnya fasilitas, minimnya pengetahuan manajerial dan kurangnya akses pasar. Kendala tersebut menunjukkan bahwa kondisi UKM masih tetap rawan, anatar lain disebabkan karena faktor internal seperti: tata kelola yang masih lemah dan bersifat tradisional dan adanya pengaruh faktor eksternal seperti pengaruh lingkungan internasional yaitu liberalisasi pasar disamping karena rendahnya keberpihakan lembaga keuangan serta kebijakan yang mendukung sektor usaha kecil.

Beberapa temuan empiris menunjukkan, UKM telah berhasil memberikan kontribusi yang positip bagi pertumbuhan ekonomi nasional namun demikian masih banyak menghadapi kendala seperti yang tersebut diatas yang menjadikan rendahnya kinerja dan daya saing. Untuk menciptakan daya saing maka perlu dilakukan peningkatan kinerja organisasi salah satunya dengan profesionalisme pengelolaan organisasi. Salah satu cara untuk melihat profesionalisme pengelolaan dalam suatu organisasi adalah sejauhmana corporate governance dalam organisasi di lingkungan UKM dilakukan dengan baik atau dengan kata lain bagaiman penerapaan good corporate governance di lingkungan UKM.

Good Corporate Governance atau GCG adalah sistem, struktur yang baik untuk mengelola perusahaan dengan tujuan untuk meningkatkan kinerja organisasi. Secara konseptual, Corporate Governance lebih menekankan bagaimana melakukan tata kelola dalam sebuah organisasi dengan memperhatikan faktor-faktor yang mempengaruhi pada proses organisasi dalam rangka memproduksi dan menjual barang dan jasa (Turnbull, 1997). Inti corporate governance pada dasarnya berfokus pada "bagaimana organisasi itu dapat berjalan dengan baik sesuai dengan tujuan yang telah ditetapkan". Syakhroza (2002) mengemukakan, bahwa corporate governance merupa- 
kan sebuah sistem yang digunakan oleh pimpinan puncak (Board) untuk mengarahkan (directing), mengendalikan (controlling) dan mengawasi (supervising) pengelolaan sumber daya dalam organisasi secara efisien, efektif, ekonomis dan produktif dengan mendasarkan prinsip GCG yaitu "transparansi, akuntabilitas, responsibilitas, independensi dan kejujuran/keadilan. Maati (1999) menjelaskan bahwa corporate governance merupakan serangkaian ukuran yang diambil dalam entitas sosial yaitu sebuah institusi untuk membantu unit-unit usaha/ekonomi untuk mengambil bagian dalam proses produksi, dengan tujuan untuk memberikan surplus bagi institusi dan memberikan kontribusi yang fair antara pihakpihak yang berkepentingan (stakeholders).

Implementasi GCG sudah menjadi tuntutan dan kebutuhan mutlak bagi perusahaan. Isu GCG adalah berkait dengan bagaimana menciptakan pengelolaan perusahaan yang professional melalui penerapan sistem akunting yang memenuhi standar, bagaimana manajemen dilengkapi dengan sistem teknologi informasi yang mendukung operasional perusahaan, serta bagaimana meningkatkan pengetahuan manajerial dan penempatan SDM yang efesien. Isu-isu ini pada akhirnya akan bermuara pada terbentuknya citra UKM yang reliable, professional, transparan dan bertanggungjawab (accountable) sebagaimana tujuan dilaksanakannya GCG.

\section{POKOK PERMASALAHAN}

Penegakan sistem governance perlu memperhatikan dua aspek: (1) governance structure yaitu tata kelola bagaimana kegiatan dalam perusahaan diorganisir dan dikoordinasikan secara bertanggung jawab; (2) governance mechanism yaitu suatu aturan main, prosedur (standard operating procedure) dan hubungan yang jelas antara pihak pengambil keputusan dengan pihak yang akan melakukan kontrol terhadap keputusan tersebut. Sistem governance yang mencakup governance structure dan governance mechanism mengacu pada penerapan governance principles (prinsip-prinsip tata kelola). Governance principles yang dimaksud dalam model, berupa: (1) transparansi yaitu peningkatan pengungkapan, teliti, tepat waktu atas informasi perusahaan; (2) akuntabilitas; (3) responsibilitas, yakni tanggung jawab perusahaan sebagai bagian dari masyarakat; (4) independensi dan (5) fairness. Penegakan sistem governance juga perlu diperhatikan aspek External Forces, yang terdiri dari legal framework, government regulation dan business environment.

Dengan dasar pemikiran tersebut maka permasalahan dalam penelitian ini dirumuskan sebagai berikut: (1). Bagaimanakah pelaksanaan GCG di lingkungan UKM di DIY, (2) Apakah pelaksanaan governance sudah memadai dari perspektif governance structure dan governance mechanism serta dari perspektif legal framework, governance regulations dan business environment, (3). Bagaimana persepsi lembaga keuangan sebagai stakeholders terhadap praktek corporate governance di lingkungan UKM, (4). Apakah terdapat perbedaan praktek governance oleh usaha skala kecil dan usaha skala menengah, (5). Apakah terdapat perbedaan kinerja antara usaha skala kecil dan usaha skala menengah berdasarkan pelaksanaan governance yang diterapkan selama ini, (6). Bagaimanakah pengaruh corporate governance terhadap kinerja perusahaan.

\section{KAJIAN TEORI \\ Konsep dan Unsur-Unsur Good Corporate Governance}

Secara konseptual good corporate governance atau tata kelola perusahaan yang baik didefinisikan sebagai struktur hubungan serta kaitannya dengan tanggung jawab diantara pihak terkait diantaranya pemegang saham, anggota dewan direksi, komisaris 
termasuk manajer, yang dirancang untuk mendorong terciptanya suatu kinerja yang kompetitif yang diperlukan dalam mencapai tujuan perusahaan, stake holders dan lingkungan dimana perusahaan itu berada (Organization Economic Cooperation and Development, 1998).

Menurut Finance Committee on Corporate Governance Malaysia, corporate governance adalah proses dan struktur yang digunakan untuk mengarahkan dan mengelola bisnis dan kegiatan perusahaan ke arah peningkatan pertumbuhan bisnis dan akuntabilitas perusahaan, dengan tujuan menaikkan nilai saham dalam jangka panjang dengan tetap memperhitungkan kepentingan stakeholders. Definisi ini menekankan bahwa sekalipun struktur corporate governance baik, namun jika prosesnya tidak berjalan sebagaimana mestinya maka tujuan akhir melindungi kepentingan pemegang saham dan stakeholders tidak akan tercapai. Shleifer dan Vishny (1997) mendefinisikan corporate governance sebagai bagian dari cara atau mekanisme untuk meyakinkan pemilik modal dalam memperoleh return yang sesuai dengan investasi yang ditanamkannya. Prowsen (1998) mengemukakan bahwa corporate governance merupakan alat untuk menjamin direksi atau manajer bertindak yang terbaik menurut kepentingan investor luar (kreditor dan investor publik).

Berdasarkan definisi di atas dapat disimpulkan, hakekatnya good corporate governance diartikan sebagai tata kelola perusahaan yang memberikan jaminan berlangsungnya system dan proses pengambilan keputusan organ perusahaan berlandaskan pada prinsip keadilan, transparan, bertanggungjawab dan akuntabel. Dalam proses pengambilan keputusan, organ perusahaan ini juga terkait dengan stakeholders perusahaan (kreditor, pemasok, masyarakat, konsumen, pemerintah, media dan LSM). Menurut Cadbury Committee dalam Ariyoto
(2000) bahwa untuk membuat corporate governance berfungsi sebagaimana mestinya, diperlukan lima kelompok yang berinteraksi yaitu: (1) tersedianya landasan hukum/jaminan hukum; (2) ditegakkannya accountability; (3) adanya fungsi supervise kinerja direksi; (4) direksi yang mengelola perusahaan dan (5) manajer beserta karyawan lainnya yang ikut membantu direksi.

Asian Development Bank (ADB) menekankan adanya unsur-unsur yang harus ada dalam corporate governance yaitu shareholders right (hak pemegang saham), equal treatment (fairness) of shareholders, disclosure (keterbukaan) dan transparansi. Unsur-unsur corporate governance berasal dari dalam perusahaan dan luar perusahaan yang dapat menjamin berfungsinya GCG, yakni:

1. Corporate Governance Internal Perusahaan Meliputi: (a) pemegang saham, (b) direksi, (c) dewan komisaris, (d) manajer, (e) karyawan/serikat pekerja, (f) system remunerasi berdasar kinerja dan (g) komite audit. Unsur-unsur yang selalu diperlukan di dalam perusahaan adalah: (a) keterbukaan dan kerahasiaan (disclosure), (b) transparansi, (c) accountability, (d) fairness, (e) aturan dari code of conduct.

2. Corporate Governance External Perusahaan

Menunjukkan unsur yang berasal dari luar perusahaan dan unsur yang selalu diperlukan diluar perusahaan. Meliputi: (a) kecukupan undang-undang dan perangkat hukum, (b) investor, (c) institusi penyedia informasi, (d) akuntan public, (e) institusi yang memihak kepentingan public bukan golongan, (f) pemberi pinjaman dan (g) pengesah legalitas. Unsur-unsur yang selalu diperlukan di luar perusahaan adalah: (a) aturan dari code of conduct, (b) Fairness, (c) Accountability, (d) jaminan hukum. Perilaku partisipasi pelaku 
Corporate Governance yang berada di dalam rangkaian unsur-unsur tersebut (internal dan external) akan menentukan kualitas Corporate Governance.

\section{Model Corporate Governance}

Tiga model Corporate Governance yang dikenal yaitu (FCGI, 2006):

1. Principal agent model (agency theory). Menurut model ini, korporasi dikelola untuk memberikan win-win solution bagi pemegang saham sebagai pemilik di satu pihak, dan manajer sebagai agen di lain pihak. Teori ini mengasumsikan, bahwa kondisi Corporate Governance suatu perusahaan akan direfleksikan secara baik dalam bentuk sentiment pasar (yaitu pasar modal, pasar produk dan pasar input).

2. The Myopic Market Model, memfokuskan pada kepentingan pemegang saham dan manajer, sentimen pasar lebih banyak dipengaruhi oleh faktor lain di luar Corporate Governance. Prinsipal dan agen lebih berorientasi pada keuntungan jangka pendek
3. Stakeholder Model, memperhatikan kepentingan pihak-pihak yang terkait dengan korporasi secara luas, artinya bahwa dalam mencapai tingkat pengembalian (return) yang menguntungkan bagi pemegang saham, manajer harus memperhatikan adanya batasanbatasan yang timbul dalam lingkungan dimana mereka beroperasi, antara lain: masalah etika dan moral, hukum, kebijakan pemerintah, lingkungan hidup, social, budaya, politik dan ekonomi.

Berdasarkan model-model Corporate Governance, model pada butir 3 nampaknya yang mendekati kesesuaian bagi perusahaan di Indonesia, yaitu adanya fokus perhatian dalam Corporate Governance adalah hubungan diantara stakeholders. Keberhasilan UKM akan tercapai apabila seluruh kepentingan stakeholders terakomodasi dengan baik. Sebagaimana diusulkan Syakhroza (2005) berkaitan dengan penyususnan model Governance UKM di Indonesia yang mendasari kajian dalam penelitian ini diperlihatkan pada gambar 1 . 


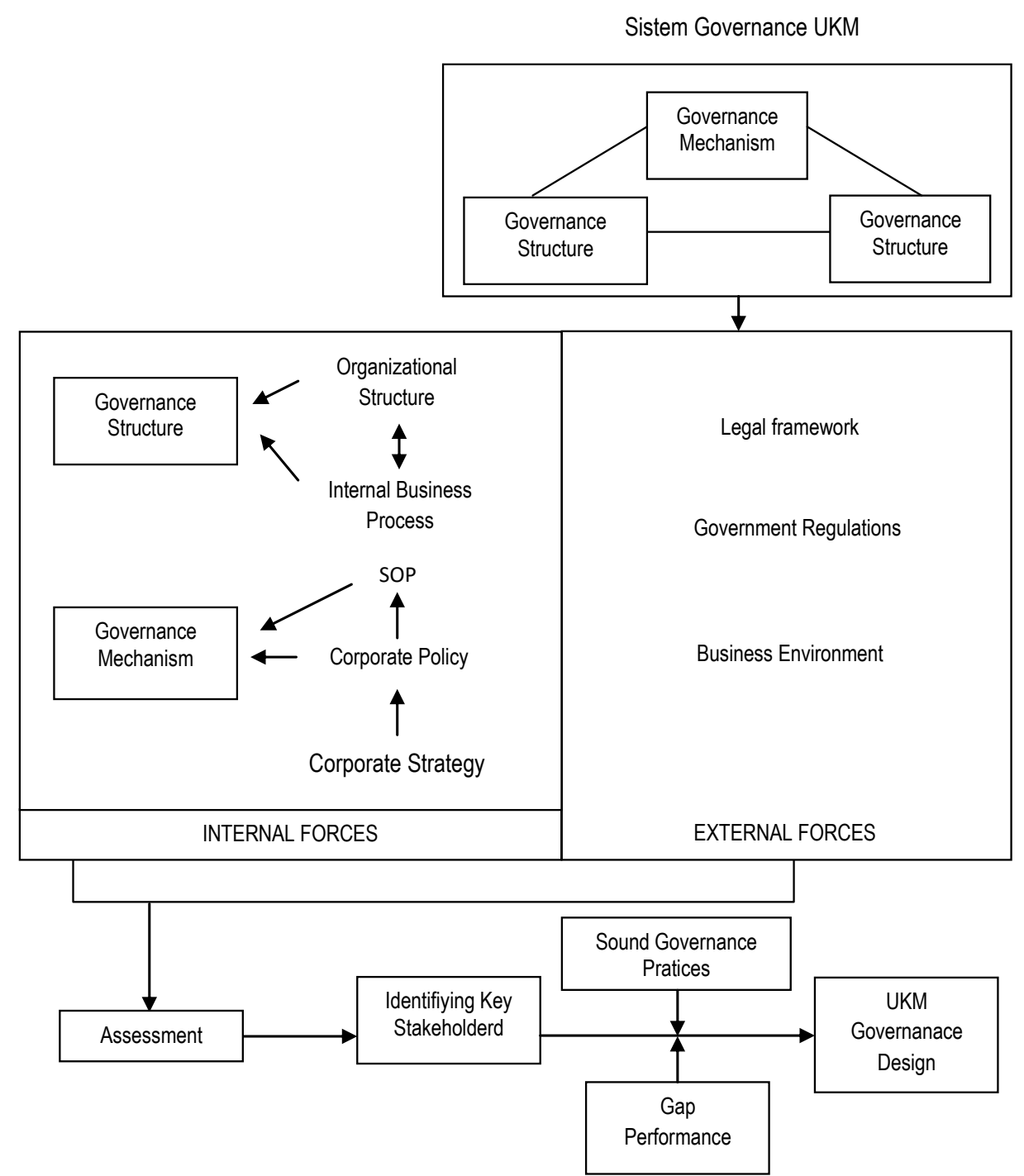

Sumber: model adopsi sistem GCG UKM (Syakhroza, 2005)

Gambar 1: Model Governance UKM

Model governance UKM, dikembangkan untuk memenuhi kebutuhan perusahaan dalam menghadapi lingkungan yang terus berubah dan tuntutan kepentingan stakeholders terhadap perusahaan. Sistem governance mencakup: (1) governance structure yaitu tata kelola bagaimana kegiatan dalam perusahaan diorganisir dan dikoordinasikan secara bertanggung jawab dan terkendali dalam rangka mengidentifikasi langkah-langkah dan kebijakan untuk memperkuat dasar pengelolaan perusahaan. 
Governance structure diawali dengan melakukan penilaian atau assessment terhadap organisasi dan proses bisnis suatu perusahaan; (2) governance mechanism yaitu suatu aturan main, prosedur (standard operating procedure) dan hubungan yang jelas antara pihak pengambil keputusan dengan pihak yang akan melakukan kontrol terhadap keputusan tersebut. Mekanisme tata kelola ini saling berkaitan dengan pengendalian intern dan lingkungan pengendalian. Sistem governance yang mencakup governance structure dan governance mechanism di atas dengan mengacu pada penerapan governance principles (prinsipprinsip tata kelola). Governance principles berupa: (1) transparansi yaitu peningkatan pengungkapan, teliti, tepat waktu atas informasi perusahaan; (2) akuntabilitas; (3) responsibilitas, yakni tanggung jawab perusahaan sebagai bagian dari masyarakat; (4) independensi dan (5) fairness. Semua elemen yang tercakup dalam governance structure dan governance mechanism merupakan bagian dari Internal Forces. Dalam penegakan sistem governance di perusahaan juga harus memperhatikan aspek External Forces, yang terdiri dari legal framework, peraturan pemerintah, (government regulations) dan lingkungan bisnis (business environment). Sesudah dilakukan penilaian pada internal forces dan external forces, untuk merumuskan model governance UKM dilakukan identifikasi atas hal-hal yang berkaitan dengan perangkat GCG (identifying key stakeholders) untuk kemudian dibandingkan dengan praktek governance.

Terbentuknya GCG akan dapat dicapai apabila perusahaan memiliki governance structure (structural governance) yang jelas dengan manajemen yang transparan, dan akuntabel dalam mengleola perusahaannya. Adanya aturan main yang jelas dan laporan yang dapat dipertanggungjawabkan akan mempermudah stakeholders melakukan pemantauan dan pengendalian terhadap manajemen. Keadilan (fairness) merupakan ukuran normative yang sering dikaitkan dengan GCG atau untuk membedakan antara Corporate Governance yang baik dan tidak. Atau dengan kata lain, pola hubungan antara stakeholders yang dikategorikan sebagai "baik" adalah melalui parameter fairness. Ariyoto (2000), menjelaskan bahwa untuk dapat menciptakan keadilan, diperlukan beberapa prasyarat yang saling terkait dan saling mempengaruhi, yaitu: transparansi, akuntabilitas, kepastian (predictability) dan partisipasi. Apabila empat karakteristik ini dapat terlaksana dengan baik, maka dampak dari Corporate Governance yang akan dirasakan oleh stakeholders adalah terciptanya keadilan dalam supra system dimana mereka saling berinteraksi satu sama lain. Transparansi, sebagai kerangka Corporate Governance harus menjamin adanya pengungkapan yang tepat waktu dan akurat untuk setiap permasalahan yang berkaitan dengan perusahaan. Pengungkapan ini meliputi: informasi mengenai keadaan keuangan, kinerja perusahaan, kepemilikan, pengelolaan perusahaan. Informasi yang diungkapkan harus disusun, diaudit, dan disajikan sesuai dengan standar kualitas.

Rendahnya kesadaran GCG menjadi penyebab tingginya resiko berinvestasi di Indonesia sehingga berdampak pada tingkat investasi dimana arus investasi langsung di Indonesia bernilai negatif pada tahun 2003. Terdapat dua faktor penyebab pemacu isu corporate governance, yaitu: (1) perubahan lingkungan yang sangat cepat yang berdampak pada perubahan peta kompetisi pasar global, (2) semakin banyak dan kompleknya pihak-pihak yang berkepentingan dengan perusahaan dan kompleknya pola ownership structures sehingga berimplikasi terhadap manajemen stakeholders (Berman,1999).

Kunci utama dibutuhkannya GCG adalah (1) sebagai upaya untuk meningkat- 
kan kinerja perusahaan melalui mekanisme supervisi atau pemantauan kinerja manajemen dan (2) sebagai upaya untuk memperkuat dan mempertegas pertanggungjawaban dewan direksi dan manajemen kepada para pemegang saham dan stakeholders lain (Keasey \& Wright, 1997).

\section{Pengembangan Good Corporate Governance di Indonesia}

Secara umum pengembangan GCG di Indonesia mencakup prinsip-prinsip pokok yakni: transparansi, akuntabilitas, fairness, dan responsibility. Menurut Daniri (2008) terdapat beberapa faktor yang dapat menjadi pemicu untuk perbaikan governance di Indonesia mencakup: (1) penegakan hukum yang baik dan memadai untuk menciptakan iklim usaha yang sehat dan didukung penerapannya secara konsisten (2) dorongan pasar dengan menekankan pada kinerja pasar untuk membangun system yang mengapresiasi penerapan GCG, dan (3) dorongan etika dimana penerapan GCG bukan disebabkan ada peraturan yang mengharuskan tapi lebih kepada kesadaran pelaku.

Dengan penerapan tata kelola yang baik maka pelaku usaha akan mendapatkan sejumlah keuntungan, yakni (FCGI, 2006): lebih mudah meningkatkan perolehan permodalan, mengurangi biaya modal, meningkatkan kinerja bisnis dan kinerja ekonomi, dan memberikan dampak yang baik dalam perolehan pendapatan.

\section{Pelaksanaan Good Corporate Governance Pada UKM}

Penerapan GCG pada dasarnya juga relevan untuk kalangan perusahaan dalam kategori perusahaan kecil dan menengah (UKM). UKM dengan struktur manajemen yang masih sederhana tentunya tidak harus mengikuti struktur manajemen di perusahaan besar, emiten dan BUMN dimana harus membentuk komisaris independent, komite audit. Isu pelaksanaan GCG di UKM berkaitan dengan persoalan: (1) bagaimana menciptakan pengelolaan perusahaan yang professional melalui penerapan system akunting dan keuangan yang memenuhi standar, (2) bagaimana manajemen dilengkapi dengan system teknologi informasi yang mendukung operasional perusahaan, (3) bagaimana meningkatkan pengetahuan manajerial dan penempatan sumber daya manusia yang efisien. Isu-isu inilah yang pada akhirnya bermuara pada terbentuknya citra UKM yang reliable dan professional, transparan dan accountable (bertanggung jawab) sebagaimana tujuan dilaksanakannya GCG.

Sebagaimana diketahui bahwa pada umumnya perusahaan kelompok UKM memiliki karakteristik khusus diantaranya adalah pengelolaan perusahaan yang masih bersifat tradisional, menggunakan system akunting dan keuangan yang sederhana, fasilitas terbatas, minimnya pengetahuan manajerial (penempatan SDM yang tidak efisien), kurangnya akses pasar, terbatasnya dan sulitnya perusahaan kecil-menengah yang menyediakan informasi keuangan yang bisa diakses oleh pihak bank terkait dengan pengucuran pinjaman yang ini disebabkan oleh rendahnya pengetahuan yang dikuasai UKM (Sutawinangun, 2004). Pihak bank sering menghadapi kendala teknis ketika akan memberikan pinjaman kepada UKM, sebab dengan keterbatasan-keterbatasan tersebut masih banyak UKM yang tidak memiliki laporan keuangan (neraca dan laporan laba rugi) dan tidak memahami bagaimana membuat laporan keuangan yang baik dan benar. Kelemahan kondisi UKM inilah yang menyulitkan bank dalam penyaluran kredit.

Berdasarkan temuan empiris dalam program pengabdian kepada masyarakat dengan topik "Pendidikan dan Pelatihan Manajemen dan Administrasi Keuangan di Kalangan Pengusaha Kecil Gerabah di 
Kasongan (Hadiyati, dkk, 2005) dinyatakan bahwa hampir seluruh peserta pelatihan belum ada yang melakukan administrasi pembukuan secara benar dan bahkan ada yang sama sekali belum pernah melakukan pembukuan keuangan. Kondisi demikian ini terjadi karena berbagai alasan yang dikemukakan peserta pelatihan antara lain: (1) Faktor internal, yang berupa kemalasan dari individu untuk melakukan pencatatan dari setiap kegiatan usahanya, dan (2) Pendapatan usaha yang diperoleh dicampur adukkan dengan konsumsi keluarga sehingga mereka mengalami kesulitan untuk mengetahui seberapa besar keuntungan yang diperoleh. Adapun permasalahan yang umumnya dihadapi para pelaku UKM tersebut antara lain: (1). Informasi pasar, (2) Informasi peraturan tata niaga impor, (3). Perolehan pinjaman dari Bank, (4). Sistem administrasi keuangan, (5). Ijin usaha, (6). Teknologi/fasilitas penunjang produksi dan pemasaran, (7) Strategi pemasaran.

Manfaat bagi perusahaan kelompok UKM dengan menerapkan prinsip dan aturan GCG dalam perusahaannya, antara lain: (1) terbukanya akses terhadap dana pinjaman, (2) terbukanya akses pasar pada skala nasional maupun internasional dan (3) terciptanya pertumbuhan UKM yang sustainable. Berdasarkan manfaat itulah kiranya cukup beralasan bahwa penerapan GCG harus segera dilakukan di lingkungan UKM agar iklim dunia usaha semakin membaik. Hal ini juga mengingat karena masih lemahnya penerapan GCG Indonesia yang sudah mencapai nilai sangat rendah yang ditunjukkan oleh indeks GCG sebesar 2,88 yang jauh di bawah negara lain seperti Malaysia dengan indeks GCG sebesar 7,72 Thailand 4,89; Singapura 8,93 dan Jepang 9,17 (Allen and Hamilton, 2000). Bagi para pelaku usaha, konsep GCG wajib diterapkan untuk menjamin kelangsungan usahanya, karena pada dasarnya GCG adalah system dan struktur untuk mengelola perusahaan dengan tujuan meningkatkan nilai pemegang saham serta berbagai pihak lain yang berkepentingan seperti kreditor, supplier, asosiasi usaha, konsumen, pekerja, pemerintah dan masyarakat luas.

Berdasarkan uraian di atas dapat dijelaskan bahwa GCG berkaitan erat dengan etika usaha, maksudnya yaitu bagaimana seharusnya sebuah usaha itu dijalankan dengan benar. Terdapat empat prinsip standar tentang berlakunya sebuah GCG pada sebuah perusahaan yaitu transparency, accountability, fairness dan responsibility (Bakrie, 2000).

\section{TINJAUAN PUSTAKA}

Sejumlah penelitian tentang corporate governance di tingkat perusahaan sebagian besar dilakukan di Amerika dan di perusahaan-perusahaan yang tergabung dalam OECD atau Organization for Economic Co-operation and Development (Shleifer and Vishny, 1997). Beberapa studi yang dilakukan untuk menginvestigasi keterkaitan corporate governance yang diterapkan dalam perusahaan dengan kinerja perusahaan. Hasil penelitian Berghe dan Ridder menunjukkan bahwa perusahaan yang memiliki poor performance disebabkan oleh poor governance. Temuan ini didukung oleh studi yang dilakukan Coobers (2003) yang menunjukkan adanya korelasi positif antara indeks corporate governance dengan kinerja perusahaan. Coobers dan Watson (2000) menyatakan bahwa pemegang saham saat ini sangat aktif dalam meninjau kinerja perusahaan, karena mereka menganggap bahwa corporate governance yang lebih baik akan memberikan imbal hasil yang lebih tinggi bagi mereka.

Survei yang dilakukan oleh perusahaan konsultan McKinsey, untuk menemukan bagaimana pemegang saham merasa dan lebih penting, menilai corporate governance pada pasar negara yang maju dan berkembang. Hasil survey menunjukkan adanya 
respon lebih dari 200 investor institusional dimana total asset yang dikelolanya sekitar \$ 3,25 triliun. Terdapat 35\% dari investor mengatakan bahwa praktek corporate governance paling tidak sama pentingnya dengan kinerja keuangan ketika mereka mengevaluasi perusahaan untuk tujuan investasi. Sementara di Amerika Latin hampir $50 \%$ dari responden mempertimbangkan praktek corporate governance lebih penting dibandingkan kinerja keuangan. Lebih dari $80 \%$ dari investor mengatakan bahwa mereka akan membayar lebih mahal untuk saham perusahaan yang memiliki corporate governance yang lebih baik (well governed company) dibandingkan perusahaan lain dengan kinerja keuangan relative sama. Temuan empiris ini menunjukkan fakta bahwa investor yang mengatakan akan memperhitungkan corporate governance ketika membuat keputusan investasi, menunjukkan suatu argumen penting bagi perbaikan system corporate governance di perusahaan.

Credit Lyonnaise Securities Asia (CLSA) pada tahun 2001 menerbitkan pemeringkatan corporate governance dari 495 perusahaan di 25 emering market dari 18 sektor ekonomi. Hasil studi CLSA menemukan bahwa ada korelasi kuat antara peringkat corporate governance dengan rasio profitabilitas dan nilai saham (price to book value). Dari 495 sampel perusahaan rata-rata skor corporate governance 55,9\%. Perusahaan tersebut menduduki peringkat lebih baik dalam kesadaran sosial dan fairness (masing-masing> 63\%), pada sisi kriteria akuntabilitas dan disiplin berada pada peringkat kategori buruk (rata-rata < $50 \%$ ). Perusahaan berada pada peringkat lebih baik untuk criteria fairness dan tanggung jawab social sementara itu ratarata skor corporate governance mencapai $55,9 \%$. Temuan empiris (Darmawati, et.al. 2003) terhadap perusahaan yang terdaftar di BEJ tahun 2001 dan 2002 yang masuk dalam pemeringkatan penerapan corporate governance dengan sample 53 perusahaan menunjukkan adanya pengaruh secara signifikan antara variable corporate governance terhadap kinerja operasi perusahaan yang diukur dari indiaktor return on equity.

Berdasarkan survey Asian

Corporate Governance Associaion tentang praktik corporate governance di Asia termasuk Indonesia terungkap bahwa semua indicator penerapan GCG ternyata berada dibawah rata-rata. Indikator ini meliputi prinsip dan praktik governance yang baik, penegakan peraturan, kondisi politik dan hukum, system akuntansi dan kultur. Survei yang dilakukan oleh World Bank pada tahun 2007 menunjukkan bahwa ada perbaikan iklim bisnis misalnya pada pembentukan usaha baru dengan percepatan pemberian izin usaha dari Departemen Kehakiman dan simplifikasi persyaratan usaha. Namun dalam urutan peringkat, Indonesia mengalami penurunan dari total 175 negara, berada di posisi 135 dan turun empat peringkat dibanding tahun sebelumnya (Bisnis Indonesia, 2008).

\section{HIPOTESIS}

Mengingat berbagai keterbatasan internal yang umumnya merupakan karakteristik usaha kecil maka keterbatasan internal ini akan mempengaruhi kinerja perusahaan (Marbun, 1996). Berdasarkan pemikiran tersebut dan temuan empiris penelitian sebelumnya, dirumuskan hipotesis berikut:

H1: Terdapat perbedaan praktek governance pada perusahaan manufaktur skala usaha kecil dan menengah.

H2: Terdapat perbedaan kinerja antara perusahaan skala usaha kecil dan menengah.

H3: Terdapat pengaruh yang positip antara corporate governance terhadap kinerja perusahaan. 
METODE PENELITIAN

Variabel Penelitian dan Pengukuran

1. Variabel yang diteliti meliputi: corporate governance, governance structure, governance mechanism, dan external forces.

2. Prinsip corporate governance meliputi 5 indikator: transparency, accountability, responsibility, dan fairness sebagai pembentuk corporate governance yang baik.

3. Governance structure meliputi 2 indikator: organisasi dan proses bisnis internal.

4. Governance mechanism meliputi 3 indikator: SOP, corporate policy, dan corporate strategy.

5. Kekuatan eksternal meliputi 3 indikator: legal framework, government regulations dan business environment.

Pengukuran variabel menggunakan skala likert berjenjang 4 dimana skor 1 bernilai pernyataan yang bersifat negatif hingga skor 4 bernilai pernyataan yang semakin positip. Untuk pertanyaan dengan alternatif jawaban yang bersifat dikotomi atau bersifat binary strickly maka nilai 0 untuk jawaban tidak dan nilai 4 untuk jawaban ya.

\section{Uji Instrumen Penelitian}

Instrumen penelitian menggunakan kuesioner yang diuji validitas dan reliabilitasnya. Uji validitas konstruk yang dilakukan menggunakan corrected items to total correlation dimana apabila angka korelasi $\geq 0.30$ maka butir kuesioner adalah valid dan jika angka korelasi < 0.30 maka bukit kuesioner adalah gugur atau tidak valid. Uji reliabilitas menggunakan Cronbach Alpha. Berdasarkan uji validitas dan reliabilitas dapat ditunjukkan bahwa untuk konstruk aspek organisasi dari 10 butir pertanyaan terdapat 3 butir yang gugur, konstruk proses bisnis internal dari 14 butir pertanyaan terdapat 1 butir pertanyaan yang gugur, konstruk strategi perusahaan dari 5 butir pertanyaan tidak ada yang gugur, konstruk kebijakan perusahaan dari 7 butir pertanyaan terdapat 2 butir pertanyaan yang gugur, konstruk SOP dari 4 butir pertanyaan tidak ada yang gugur, konstruk peraturan pemerintah dari 7 butir pertanyaan terdapat 2 butir pertanyaan yang gugur, konstruk lingkungan bisbis dari 8 butir pertanyaan terdapat 2 butir pertanyaan yang gugur, konstruk legal framework dari 3 pertanyaan tidak ada yang gugur, konstruk transparansi dari 13 butir pertanyaan terdapat 5 butir pertanyaan yang gugur, konstruk independensi terdiri dari 3 butir pertanyaan dan terdapat 1 butir pertanyaan yang gugur, konstruk akuntabilitas dari 7 butir pertanyaan tidak ada yang gugur, konstruk responsibility dari 5 butir pertanyaan terdapat 2 butir pertanyaan yang gugur dan konstruk fairness dari 3 butir pertanyaan tidak ada butir pertanyaan yang gugur.

\section{Sampel Penelitian}

Sampel penelitian ini adalah pemilik perusahaan manufaktur skala usaha kecil dan menengah yang ada di propinsi DIY. Teknik pengambilan sampel yang digunakan adalah purposive random sampling yang dikombinasikan dengan convenience sampling. Untuk sampel UKM digunakan kriteria jumlah tenaga kerja $5 \mathrm{~s} / \mathrm{d}$ 19 orang untuk usaha skala kecil dan 20-99 tenaga kerja untuk usaha menengah. Sampel yang diambil sebanyak 60 UKM dan untuk lembaga keuangan (bank) adalah yang memberikan pelayanan penyaluran pinjaman kepada UKM di propinsi DIY yakni diambil sebanyak 10 lembaga keuangan untuk memberikan penilaian mengenai corporate governance di perusahaan skala UKM.

\section{Metode Analisis Data}

Metode analisis yang digunakan adalah deskriptif dan inferensial. Untuk 
metode deskriptif digunakan alat mean aritmathic dan quartil untuk memecahkan permasalahan yang bersifat desriptif. Metode inferensial digunakan untuk memcahkan permasalahan yang membutuhkan pengujian hipotesa dengan menggunakan alat tes dua mean dan regresi dengan uji t.

\section{Hasil Analisis dan Pembahasan Deskripsi UKM Sampel Penelitian}

Berdasarkan hasil survei terhadap 60 responden (pengusaha/pemilik) perusahaan manufaktur skala usaha kecil menengah (UKM) di wilayah DIY tahun 2007/2008 menunjukkan temuan sebagai berikut:

Tabel 1: Deskripsi Umum UKM

\begin{tabular}{lcc}
\hline \multicolumn{1}{c}{ Deskripsi } & Frekuensi & Persentase \\
\hline Badan Hukum & & \\
Perseorangan & 50 & $88,3 \%$ \\
CV & 10 & $16,7 \%$ \\
Jumlah Tenaga Kerja & & \\
5-19 orang & 43 & $71,7 \%$ \\
20 -99 orang & 17 & $28,3 \%$ \\
Status & & \\
Pemilik & 7 & $11,7 \%$ \\
Pemilik dan Pemimpin & 53 & $88,3 \%$ \\
Lama Usaha & & \\
$2-9$ tahun & 34 & $56,7 \%$ \\
$10-17$ tahun & 20 & $33,3 \%$ \\
$18-25$ tahun & 4 & $6,7 \%$ \\
$26-32$ tahun & 2 & $3,3 \%$ \\
Rerata Penjualan/tahun & & \\
<18 juta/tahun & 14 & $23,3 \%$ \\
18 juta s/d 80 juta/tahun & 28 & $46,7 \%$ \\
Lebih dari 80 juta/tahun & 18 & $30,0 \%$ \\
\hline
\end{tabular}




\section{Praktek Corporate Governance}

Untuk mengetahui sejauhmana praktek corporate governance telah dilakukan pada 60 sampel UKM, dapat diketahui melalui analisis scoring corporate governance. Penilaian corporate governance pada perusahaan dilakukan melalui kuesioner yang dirancang dengan mengembangkan pertanyaan-pertanyaan yang dikelompokkan ke dalam 5 kriteria utama yang dianggap sebagai pembentuk konsep corporate governance, yaitu transparancy, responsibility, accountability, independency dan fairness. Pemberian bobot ditentukan sebesar 15\% pada masing-masing aspek corporate governance (CLSA, 2000).

Berdasarkan hasil analisis final score corporate governance menunjukkan bahwa rata-rata skor corporate governance sebesar 0.3798 atau $37.98 \%$. Hal ini dapat diartikan bahwa praktek corporate governance di lingkungan UKM masih rendah atau buruk karena rata-rata skor berada di bawah $50 \%$.

Ditinjau dari masing-masing aspek yaitu transparancy, responsibility, accountability, independency dan fairness menunjukkan tidak terdapat aspek corporate governance yang menonjol karena masingmasing aspek memiliki skor sangat buruk (dibawah 10\%). Skor untuk kategori transparency $7.17 \%$, skor responsibility $5.25 \%$, skor kategori accountability 9.04\%, skor kategori independency $7.13 \%$ dan skor fairness $9.39 \%$.

Hasil analisis Quartil terhadap final score corporate governance menunjukkan bahwa terdapat 16 perusahaan $(26.7 \%$ dari perusahaan sampel) memiliki rata-rata skor corporate governance peringkat rendah yaitu kurang dari $30.88 \%$. Perusahaan dengan skor corporate governance peringkat sedang yaitu antara $30.88 \%-45.25 \%$ sebanyak 31 perusahaan $(51.67 \%$ dari perusahaan sampel) dan terdapat 13 perusahaan (21.7\% dari perusahaan sampel) memiliki skor corporate governance peringkat tinggi yakni di atas $45.25 \%$.

Dengan analsis Quartil jika mengacu batasan skor corporate governance sebesar 0.50 maka nampak sebagian besar perusahaan yakni sebanyak $85 \%$ memiliki angka peringkat corporate governance rendah (skor di bawah 50\%) dan hanya 15\% perusahaan dalam peringkat cukup baik dengan skor di atas 0.50. Kondisi demikian menggambarkan masih buruknya praktek corporate governance di lingkungan perusahaan

Lembaga keuangan sebagai stakeholders UKM memberikan penilaian kepada pengelola UKM mengenai praktek corporate governance, menunjukkan adanya penilaian atau persepsi negatif terhadap praktek corporate governance di lingkungan UKM. Hasil final score corporate governance menunjukkan skor rata-rata sebesar 0.40 yang berarti masih di bawah nilai ratarata 0.50 . Kecenderungan penilaian yang menunjukkan masih buruknya praktek corporate governance di lingkungan UKM dari pihak stakeholders konsisten dengan hasil penilaian dari para pengelola perusahaan (self assessment for good corporate governance).

Deskrepsi Governance Structure di UKM

Sistem tata kelola pada UKM ditinjau dari struktur tata kelola yaitu sejauhmana aktivitas dalam perusahaan diorganisir dan dikoordinasikan secara bertanggung jawab, dalam penelitian ini menunjukkan bahwa sebagian besar UKM belum sepenuhnya mengorganisir atau mengkoordinir perusahaannya secara bertanggung jawab. Belum adanya struktur organisasi secara formal yang menggambarkan secara lebih jelas tugas dan tanggung jawab karyawan merupakan salah satu kelemahan bagi pendukung penegakan sistem tata kelola. Aspek pendukung penegakan sistem tata kelola yang menunjukkan kelemahan di lingkungan 
SIIERGH Vol. 10 No. 2, JUNI 2008: 121 - 140

UKM ialah pemanfaatan tehnologi informasi melalui internet. Secara lebih detail tata kelola atau governance structure dalam UKM ditunjukkan pada table berikut:

Tabel 2: Deskripsi Governance Structure

\begin{tabular}{|c|c|c|}
\hline No. & Aspek Organisasi & Hasil \\
\hline 1 & Kepemilikan ijin usaha & $\begin{array}{l}\text { Belum memiliki ijin usaha (48,3\%), sudah memiliki (45\%), sedang } \\
\text { mengurus ijin }(1,7 \%)\end{array}$ \\
\hline 2 & Pembagian kerja dan tanggungjawab & $\begin{array}{l}\text { Ada pembagian yang jelas meskipun belum membuat struktur } \\
\text { organisasi }(46,7 \%) \text {, ada pembagian yang jelas dan ada struktur } \\
\text { organisasi sederhana }(38,3 \%)\end{array}$ \\
\hline 3 & Pembuatan/persiapan perencanaan produksi & $\begin{array}{l}\text { Aktif membuat perencanaan secara periodic }(58,3 \%) \text {, jarang } \\
\text { melakukan perencanaan }(31,7 \%) \text {, belum pernah melakukan } \\
\text { perencanaan produksi }(10 \%)\end{array}$ \\
\hline 4 & Penyusunan perencanaan keuangan & $\begin{array}{l}\text { Melakukan perencanaan secara periodik }(60 \%) \text {, membuat } \\
\text { perencanaan jika ingat saja }(26,7 \%) \text {, belum pernah membuat } \\
\text { perencanaan keuangan }(13,3 \%)\end{array}$ \\
\hline 5 & Penetapan rencana target & $\begin{array}{l}\text { Menetapkan target secara formal }(58,3 \%) \text {, kadang-kadang }(25 \%) \text {, } \\
\text { tidak pernah }(16,7 \%)\end{array}$ \\
\hline 6 & Peraturan tata tertib kerja karyawan & $\begin{array}{l}\text { Memiliki peraturan }(35 \%) \text {, belum memiliki }(45 \%) \text {, sedang } \\
\text { mempersiapkan/proses }(8,3 \%) \text {, akan berusaha membuat peraturan } \\
(11,7 \%)\end{array}$ \\
\hline 7 & kepemilikan NPWP & $\begin{array}{l}\text { Belum memiliki NPWP }(53,3 \%) \text {, belum memiliki tetapi berusaha } \\
\text { memiliki }(5 \%) \text {, telah memiliki NPWP }(40 \%) \text {, sedang mengurus } \\
\operatorname{NPWP}(1,7 \%)\end{array}$ \\
\hline No. & Proses Bisnis Internal & Hasil \\
\hline 1 & Produk terdaftar di dinas perindustrian & $\begin{array}{l}\text { Produk belum terdaftar }(46,7 \%) \text {, berencana mendaftarkan }(8,3 \%) \text {, } \\
\text { mengurus proses }(3,3 \%)\end{array}$ \\
\hline 2 & Tingkat kerusakan produk & $\begin{array}{l}\text { Sangat rendah }(58,3 \%) \text {, jarang terjadi kerusakan }(25 \%) \text {, sering } \\
\text { mengalami kerusakan }(16,7 \%)\end{array}$ \\
\hline 3 & $\begin{array}{l}\text { Penggunaan piranti komputer dalam } \\
\text { menunjang kelancaran bisnis }\end{array}$ & $\begin{array}{l}\text { Belum menggunakan }(38,3 \%) \text {, ingin menggunakan tapi da } \\
\text { keterbatasan dana untuk pengadaan }(18,3 \%) \text {, telah menggunakan } \\
\text { untuk kelancaran usaha }(43,4 \%)\end{array}$ \\
\hline 4 & $\begin{array}{l}\text { Pemanfaatan internet untuk memasarkan } \\
\text { produk }\end{array}$ & $\begin{array}{l}\text { Belum memanfaatkan }(43,3 \%) \text {, tidak memanfaatkan karena tidak } \\
\text { paham }(33,3 \%) \text {, sudah memanfaatkan }(23,4 \%)\end{array}$ \\
\hline 5 & $\begin{array}{l}\text { Pemanfaatan internet untuk mencari } \\
\text { informasi pasar }\end{array}$ & Belum memanfaatkan $(71,7 \%)$, rutin memanfaatkan $(28,3 \%)$ \\
\hline 6 & Kepemilikan mitra usaha & Memiliki (60\%), tidak memiliki (40\%) \\
\hline 7 & Pemanafaatan internet untuk komunikasi & $\begin{array}{l}\text { Memanfaatkan untuk berkomunikasi dengan pemasok dan } \\
\text { pelanggan }(25 \%) \text {, belum memanfaatkan }(75 \%)\end{array}$ \\
\hline 8 & Adminstrasi/pembukuan keuangan & $\begin{array}{l}\text { Tidak pernah membuat karena tidak paham }(8,3 \%) \text {, kadang-kadang } \\
\text { melakukan pencatatan }(31,7 \%) \text {, disiplin melakukan pencatatan } \\
(60 \%)\end{array}$ \\
\hline 9 & Pemisahan keuangan pribadi dan usaha & $\begin{array}{l}\text { Belum melakukan pemisahan keuangan pribadi dan usaha }(61,7 \%) \text {, } \\
\text { kadang-kadang }(25 \%) \text {, sudah }(13,3 \%)\end{array}$ \\
\hline 10 & Usaha menjalin kemitraan dengan pihak lain & $\begin{array}{l}\text { Tidak berupaya karena ingin bebas berusaha }(23,3 \%) \text {, sudah } \\
\text { berupaya }(26,7 \%) \text {, sudah ada mitra usaha tapi hanya pemasok } \\
(18,3 \%) \text {, menjalin dengan berbagai pihak }(31,7 \%)\end{array}$ \\
\hline 11 & $\begin{array}{l}\text { Upaya menjalin hubungan baik dengan } \\
\text { pelanggan }\end{array}$ & $\begin{array}{l}\text { Jarang karena tidak ada komplain (5\%), sering dilakukan }(45 \%) \text {, } \\
\text { selalu dilakukan karena merupakan komitmen }(50 \%)\end{array}$ \\
\hline 12 & Kerjasama dengan bank dalam permodalan & $\begin{array}{l}\text { Tidak tertarik ( } 15 \%) \text {, sedang berusaha }(26,7 \%) \text {, sudah berusaha } \\
\text { dan dalam proses persetujuan } 11,7 \%) \text {, selalu bekerjasama dengan } \\
\text { bank }(46,7 \%)\end{array}$ \\
\hline 13 & Teknologi proses produksi & $\begin{array}{l}\text { Belum menggunakan dan masih tradisional }(46,7 \%) \text {, sudah } \\
\text { menggunakan peralatan mesin }(53,3 \%)\end{array}$ \\
\hline
\end{tabular}


Deskrepsi Governance Mechanism di UKM Governance mechanism menunjukkan suatu aturan main, prosedur (standard operating procedure) dan hubungan yang jelas antara pihak pengambil keputusan dengan pihak yang akan melakukan kontrol terhadap keputusan tersebut. Mekanisme tata kelola ini saling berkaitan dengan pengendalian intern dan lingkungan pengendalian. Berdasarkan hasil penelitian dapat ditunjukkan deskripsi mekanisme tata kelola sebagai berikut:

Tabel 3: Deskripsi Governanace Mechanism

\begin{tabular}{|c|c|c|}
\hline No & Aspek Corporate Strategy & Hasil \\
\hline 1 & Kepemilikan strategi bisnis & Punya $(78,3 \%)$, tidak punya $(21,7 \%)$ \\
\hline 2 & $\begin{array}{l}\text { Strategi peningkatan mutu sebagai prioritas } \\
\text { utama perusahaan }\end{array}$ & $\begin{array}{l}\text { Belum menjadi prioritas }(16,7 \%) \text {, kadang-kadang menjadi prioritas } \\
(15 \%) \text {, dilakukan terus menerus }(45 \%) \text {, selalu menjadikan prioritas } \\
\text { utama }(23,3 \%)\end{array}$ \\
\hline 3 & $\begin{array}{l}\text { Strategi peningkatan pelayanan kepada } \\
\text { pelanggan menjadi prioritas perusahaan }\end{array}$ & $\begin{array}{l}\text { Menempatkan pentingnya strategi pelayanan }(95 \%) \text {, menganggap } \\
\text { pelayanan bukan prioritas }(5 \%)\end{array}$ \\
\hline 4 & $\begin{array}{l}\text { Strategi perusahaan ditinjau kembali sesuai } \\
\text { perubahan }\end{array}$ & $\begin{array}{l}\text { Perlu ditinjau sesuai perubahan yang ada }(90 \%) \text {, tidak perlu ditinjau } \\
(10 \%)\end{array}$ \\
\hline 5 & $\begin{array}{l}\text { Penetapan strategi bisnis sebagai hal } \\
\text { penting }\end{array}$ & Menganggap penting (90\%), tidak penting (10\%) \\
\hline No & Aspek Corporate Policy & Hasil \\
\hline 1 & Pedoman tertulis job description & $\begin{array}{l}\text { Punya pedoman pembagian tugas (45\%), tidak memiliki }(55 \%) \text {, } \\
\text { punya tapi tidak difungsikan }(5 \%)\end{array}$ \\
\hline 2 & Pedoman tertulis keselamatan kerja & Punya pedoman keselamatan kerja $(16,7 \%)$, belum punya $(83,3 \%)$ \\
\hline 3 & $\begin{array}{l}\text { Pedoman tertulis tentang penetapan standar } \\
\text { mutu }\end{array}$ & $\begin{array}{l}\text { Punya pedoman standar mutu }(38,3 \%) \text {, sedang berupaya membuat } \\
(13,3 \%) \text {, belum punya }(61,6 \%)\end{array}$ \\
\hline 4 & Penetapan gaji sesuai UMR & $\begin{array}{l}\text { Belum menetapkan sesuai UMR }(61,7 \%) \text {, mendekati UMR }(25 \%) \text {, } \\
\text { sudah membayar sesuai UMR }(13,3 \%)\end{array}$ \\
\hline 5 & $\begin{array}{l}\text { Penyelenggaran program pelatihan bagi } \\
\text { karyawan }\end{array}$ & $\begin{array}{l}\text { Telah menyelenggarakan pelatihan ( } 45 \%) \text {, belum } \\
\text { menyelenggarakan }(41,7 \%) \text {, jarang menyelenggarakan }(13,3 \%)\end{array}$ \\
\hline No & SOP & Hasil \\
\hline 1 & Prosedur pedoman kerja bagi karyawan & $\begin{array}{l}\text { Punya pedoman kerja }(48,3 \%) \text {, rencana menyusun }(15 \%) \text {, tidak } \\
\text { punya }(36,7 \%) \text {, }\end{array}$ \\
\hline 2 & $\begin{array}{l}\text { Upaya melakukan pencatatan sesuai } \\
\text { prosedur akuntansi }\end{array}$ & $\begin{array}{l}\text { Tidak melakukan karena sulit }(26,7 \%) \text {, berusaha melakukan }(15 \%) \text {, } \\
\text { sering melakukan meskipun sederhana }(45 \%) \text {, selalu melakukan } \\
\text { sesuai prosedur }(13,3 \%)\end{array}$ \\
\hline 3 & $\begin{array}{l}\text { Pemilikan prosedur perlindungan } \\
\text { keselamatan dan kesehatan bagi karyawan }\end{array}$ & Punya prosedur K3 $(43,3 \%)$, tidak memiliki prosedur K3 $(56,7 \%)$ \\
\hline 4 & $\begin{array}{l}\text { Penetapan secara tertulis tentang proses } \\
\text { produksi }\end{array}$ & Belum menetapkan $(51,7 \%)$, sudah menetapkan $(48,3 \%)$ \\
\hline
\end{tabular}




\section{Deskripsi External Force}

Dalam penegakan sistem governance di perusahaan harus memperhatikan pula aspek External Forces, yang terdiri dari legal framework, peraturan pemerintah, (government regulations) dan lingkungan bisnis (business environment). Berdasarkan hasil penelitian dapat ditunjukkan deskripsi kekuatan eksternal sebagai berikut:

Tabel 4: Deskripsi External Force

\begin{tabular}{|c|c|c|}
\hline No & Peraturan Pemerintah & Hasil \\
\hline 1 & $\begin{array}{l}\text { Pelayanan pemerintah dalam perijinan } \\
\text { usaha }\end{array}$ & $\begin{array}{l}\text { Lemahnya pelayanan }(13,3 \%) \text {, rantai birokrasi panjang dan biaya } \\
\text { tinggi }(60 \%) \text {, pelayanan mudah tapi biaya mahal }(10 \%) \text {, ada } \\
\text { kemudahan tapi biaya mahal }(16,7 \%)\end{array}$ \\
\hline 2 & Informasi peluang pasar & $\begin{array}{l}\text { Bermanfaat bagi usaha }(48,3 \%) \text {, layanan tidak memberikan manfaat } \\
(51,7 \%)\end{array}$ \\
\hline 3 & $\begin{array}{l}\text { Kemudahan permodalan melalui lembaga } \\
\text { keuangan }\end{array}$ & $\begin{array}{l}\text { Membantu dalam menjalankan usaha }(50 \%) \text {, tidak banyak } \\
\text { membantu }(50 \%)\end{array}$ \\
\hline 4 & $\begin{array}{l}\text { Kebijakan pemerintah dalam menumbuhkan } \\
\text { iklim usaha }\end{array}$ & $\begin{array}{l}\text { Kebijakan belum memihak kepentingan usaha }(63,4 \%) \text {, cukup } \\
\text { mendukung }(18,3 \%) \text {, kebijakan sudah sangat mendukung }(18,3 \%)\end{array}$ \\
\hline 5 & Pembinaan melalui penyuluhan/pelatihan & $\begin{array}{l}\text { Pembinaan oleh pemerintah memberikan manfaat bagi usaha } \\
(78,4 \%) \text {, kurang memberikan manfaat }(21,6 \%)\end{array}$ \\
\hline No & Aspek Lingkungan Bisnis & Hasil \\
\hline 1 & $\begin{array}{l}\text { Pengaruh persaingan terhadap } \\
\text { kemajuan/kinerja perusahaan }\end{array}$ & $\begin{array}{l}\text { Dampak pesaing menghambat kinerja }(63,3 \%) \text {, mendorong } \\
\text { perusahaan untuk lebih meningkatan kinerja }(36,7 \%)\end{array}$ \\
\hline 2 & Pandangan terhadap perdagangan bebas & $\begin{array}{l}\text { Perdagangan bebas mampu menjadi peluang }(51,7 \%) \text {, } \\
\text { perdagangan bebas menjadi penghambat usaha }(48,3 \%)\end{array}$ \\
\hline 3 & Pengaruh internet bagi kemajuan bisnis & $\begin{array}{l}\text { Internet mampu membantu perkembangan usaha }(56,7 \%) \text {, belum } \\
\text { banyak membantu }(35 \%) \text {, sedikit membantu usaha }(8,3 \%)\end{array}$ \\
\hline 4 & Pandangan terhadap pembebanan pajak & $\begin{array}{l}\text { Pajak menjadi beban yang memberatkan usaha }(85 \%) \text {, pajak tidak } \\
\text { memberatkan usaha }(15 \%)\end{array}$ \\
\hline 5 & $\begin{array}{l}\text { Pengaruh perubahan mata uang terhadap } \\
\text { bisnis }\end{array}$ & $\begin{array}{l}\text { Perubahan kurs tidak mempengaruhi usaha }(38,3 \%) \text {, mem- } \\
\text { pengaruhi usaha }(61,7 \%)\end{array}$ \\
\hline 6 & Penetapan bunga kredit & Bunga kredit memberatkan usaha ( $60 \%)$, tidak memberatkan $(60 \%)$ \\
\hline No & Aspek Kerangka Hukum & Hasil \\
\hline 1 & Hukum perlindungan bagi perusahaan kecil & $\begin{array}{l}\text { Belum melindungi usaha kecil }(66,7 \%) \text {, kerangka hukum } \\
\text { memberikan dampak positip usaha }(33,3 \%)\end{array}$ \\
\hline 2 & $\begin{array}{l}\text { Peraturan yang terkait dengan layanan } \\
\text { kemudahan memperoleh modal }\end{array}$ & $\begin{array}{l}\text { Belum merasakan manfaatnya }(63,3 \%) \text {, berdampak positip dalam } \\
\text { memperoleh layanan modal }(36,7 \%)\end{array}$ \\
\hline 3 & $\begin{array}{l}\text { Peraturan pemerintah dalam mendorong } \\
\text { kemitraan }\end{array}$ & $\begin{array}{l}\text { Belum mampu mendorong kemitraan }(83,3 \%) \text {, mampu mendorong } \\
\text { kemitraan }(16,7 \%)\end{array}$ \\
\hline
\end{tabular}


Uji Perbedaan Praktek Corporate Governance dan Kinerja UKM

Berdasarkan uji beda 2 mean dengan $\mathrm{T}$ test menghasikan temuan bahwa tidak ada perbedaan rata-rata skor corporate governance antara responden perusahaan kecil dan perusahaan menengah, yang ditunjukkan oleh angka probabilitas 0,091 (p $>0,50)$ dan nilai t sebesar -1.178, jika diasumsikan varians sama. Atau dengan kata lain bahwa rata-rata skor corporate governance antara kedua kelompok usaha tersebut adalah sama secara statistik. Hasil uji ini menunjukkan bahwa H1 (Hipotesa 1) adalah ditolak. Rata-rata skor corporate governance untuk perusahaan skala usaha kecil sebesar 0.3648 sedangkan rata-rata skor corporate governance perusahaan skala menengah adalah 0.4179. Peringkat corporate governance kedua kelompok perusahaan sama-sama berada dalam peringkat rendah (skor di bawah 0.50).

Hasil analisis uji beda 2 mean dengan uji $\mathrm{t}$ menunjukkan secara statistik ada perbedaan kinerja diantara kelompok usaha kecil dengan kelompok usaha menengah, yang diindikasikan oleh nilai t sebesar 5.497 dengan tingkat signifikan $0,00(\mathrm{p}<$ $0,05)$, jika diasumsikan varians sama. Kinerja ditunjukkan dari rata-rata produktivitas pernjualan, dimana rata-rata produktivitas penjualan kelompok perusahaan kecil adalah sebesar $41.064 \quad$ (Rp.41,064 juta/tahun) sementara kelompok perusahaan menengah sebesar 152.088 ( Rp.152.088 juta/tahun). Hasil uji ini menunjukkan bahwa H2 (Hipotesa 2) adalah diterima.

\section{Pengaruh Corporate Governance Ter- hadap Kinerja UKM}

Untuk menganalisis pengaruh corporate governance terhadap kinerja yang diukur dari produktivitas penjualan, dalam penelitian ini digunakan alat uji parametrik yaitu regresi dan uji t. Metode ini mensyaratkan data berdistribusi normal. Uji normalitas data produktivitas penjualan melalui kurtosis dan skewness. Hasil rasio skewness adalah 1.1941 dan nilai kurtosis sebesar -1.1727. Sebagai pedoman jika rasio skewness dan kurtosis berada di antara -2 sampai +2 maka dikatakan distribusi adalah normal. Uji normalitas data corporate governance dilakukan dengan cara yang sama dengan hasil nilai rasio skewness $=2$ sedangkan nilai rasio kurtosis $=0.2599$. Rasio skewness dan kurtosis berada di antara -2 sampai dengan +2 maka distribusi data corporate governance adalah normal.

Berdasarkan hasil analisis regresi diperoleh nilai koefisien regresi (Score CG) adalah positip yakni sebesar 2,353 dengan tingkat signifikansi sebesar 0,048 . Hasil ini menunjukkan bahwa terdapat arah hubungan yang positip antara corporate governance dengan kinerja UKM. Berdasarkan hasil uji t dapat ditunjukkan bahwa terdapat pengaruh yang positip dan signifikan antara corporate governance terhadap kinerja UKM dengan tingkat sigifikansi sebesar $0,048(\mathrm{p}<0,05)$. Temuan studi ini menunjukkan bahwa semakin tinggi nilai corporate governance atau score CG maka kinerja UKM akan semakin meningkat. Hasil uji ini menunjukkan bahwa H3 (Hipotesa 3) diterima.

\section{PENUTUP}

\section{Kesimpulan}

1. Praktek corporate governance pada UKM menunujukkan bahwa perusahaan berada pada peringkat buruk yang ditandai oleh rendahnya skor corporate governance yakni sebesar 0.3798 (kurang dari 0.50).

2. Berdasarkan pada kategori pemeringkatan skor corporate governance dengan metode quartile menunjukkan $26.7 \%$ perusahaan berada pada kategori corporate governance rendah dengan skor $<0.3088$, sebanyak $51.7 \%$ perusahaan dalam kategori corporate 
governance cukup dengan skor 0.30880.4525 dan $21.7 \%$ perusahaan dalam kategori tinggi dengan skor corporate governance $>0.4525$. Namun demikian secara umum dengan mendasarkan peringkat corporate governance yang dapat diterima yaitu skor 0.50 (rule of tumb) maka sebagian besar perusahaan $(85 \%)$ berada pada peringkat buruk yang diindikasikan oleh skor corporate governance $<0.50$.

3. Pada perpektif governance structure baik dalam aspek organisasi maupun proses bisnis internal dinilai belum mendukung dalam penegakan system governance perusahaan. Hal ini mengindikasikan bahwa aktivitas-aktivitas dalam perusahaan belum diorganisi/dikoordinasikan secara bertanggungjawab.

4. Pada perspektif governance mechanism yang terkait dengan aspek corporate strategy, corporate policy dan standard operating procedure dinilai memadai atau mendukung bagi penegakan system governance di perusahaan. Hal ini mengindikasikan adanya peraturan dan prosedur operasi yang ada pada perusahaan mampu untuk mendukung untuk penegakan governance.

5. Faktor kekuatan eksternal menunjukkan bahwa governance regulation, business environment dan legal framework belum memadai untuk mendukung penegakan system atau pelaksanaan governance perusahaan. Kecenderungan ini ditandai oleh tingginya prosentase pernyataan negatif dari responden terhadap ketiga asperk tersebut.

6. Berdasarkan hasil uji beda ditunjukkan bahwa tidak ada perbedaan rata-rata skor corporate governance antara perusahaan kecil dan perusahaan menengah. Pelaksanaan corporate governance yang berlangsung di kelompok usaha kecil dan menengah adalah sama dimana peringkat corporate governance kedua kelompok perusahaan berada dalam peringkat rendah (skor di bawah 0.50 )

7. Terdapat perbedaan kinerja antara kelompok usaha kecil dengan kelompok usaha menengah. Rata-rata produktivitas penjualan usaha kecil adalah $\mathrm{Rp}$ 41,064 juta/tahun dan usaha menengah adalah Rp. 152.088 juta /tahun).

8. Terdapat pengaruh yang positip dan signifikan antara praktek corporate governance terhadap kinerja UKM. Hal ini menunjukkan bahwa semakin tinggi nilai Corporate Governance maka kinerja perusahaan semakin tinggi.

\section{Saran}

\section{Bagi UKM}

Perlu dilakukan upaya pembenahan tata kelola usaha baik dalam hal struktur maupun mekanisme pengelolaan usaha. Pembenahan antara lain dilakukan dengan: (a) melakukan system pencatatan keuangan sesuai dengan prosedur akuntansi sehingga UKM mampu menyediakan informasi keuangan perusahaan yang dibutuhkan lembaga keuangan guna penyaluran modal, (b) meningkatkan kemampuan manajerial sehingga dapat mengelola SDM dengan baik dan mampu menyusun perancangan strategis berkaitan dengan pengembangan bisnis, (c) meningkatkan kemampuan pemanfaatan teknologi informasi dengan ikut serta dalam kegiatan pelatihan sehingga dapat bermanfaat dalam pengembangan usaha, (d) meningkatkan jalinan kemitraan baik dengan pelanggan, pemasok, lembaga keuangan dan pemerintah sehingga dapat diperoleh manfaat yang optimal dari kerjasama tersebut, (e) membakukan pedoman dan prosedur kerja sehingga akan memudahkan pembagian tanggungjawab kerja dan 
memudahkan pelaksanaan kerja, (f). merancang strategi untuk mengantisipasi perubahan lingkungan eksternal sehingga mampu menghadapi perubahan tersebut, misalnya dengan mengikuti perkembangan pasar, perkembangan teknologi, perubahan permintaan produk, perubahan selera konsumen dan sebagainya.

2. Bagi Pemeritah, Perguruan Tinggi dan lembaga terkait

Perlu dilakukan upaya peningkatan pembinaan kepada pelaku UKM guna perbaikan corporate governance baik melalui: (1) program pelatihan (administrasi pembukuan, perancangan strategi bisnis, pemanfaatan teknologi informasi, perncangan desaign produk dan sebagainya), (2). peningkatan kemampuan manajerial khususnya dalam tata kelola usaha, (3) mengintensifkan pendapingan bagi pelaku UKM seperti menjadikan sentra industri sebagai kawasan binaan, (4) meningkatan pemahaman terhadap orientasi kewirausahaan sehingga dapat menjadi salah satu motivator dalam peningkatan kinerja, (5) meningkatkan monitoring dan upaya peningkatan kesadaran bagi para pelaku usaha melalui kegiatan penyuluhan dalam hal penegakan transparansi, akuntabilitas, fairness dan resposibility.

\section{Keterbatasan Penelitian}

1. Penelitian yang dilakukan memiliki keterbatasan sampel penelitian sehingga disarankan untuk penelitian selanjutnya jumlah sampel dapat ditambah misalanya dengan mempertimbangkan keterwakilan setiap jenis industri yang ada pada kelompok UKM (pangan, sandang dan kulit, kimia dan bahan bangunan, logam dan elektronika, kerajinan).

2. Model penelitian ini adalah regresi konvensional yang hanya menggambarkan hubungan searah antara 1 variabel independent dengan satu variable dependen dimana dalam model penelitian ini skor corporate governance sebagai variebel independent dan produktivitas penjualan (pengukur kinerja) sebagai variable dependen. Dalam model ini hanya menunjukkan corporate governance berpengaruh langsung terhadap kinerja. Dalam literatur disebutkan bahwa corporate governance dapat berpengaruh langsung tapi juga bisa berpengaruh tidak langsung terhadap kinerja. Dengan demikian penelitian lanjutan perlu dilakukan dengan mengakomodasi adanya pengaruh tidak langsung maupun pengaruh langsung dari corporate governance terhadap kinerja. Sehingga diharapkan dapat teridentifikasi beberapa konstruk, indikator yang membentuk corporate governance.

\section{DAFTAR PUSTAKA}

Anonim. (2006). Corporate Governance Self Assessment Checklist. www.fegi.or.id

Abor, Joshua, and Nicholas biekpe. Does Corporate Governance Affect the Capital Structure Decisions of Ghanaian SMEs. University of Stellenbosch Business School, South Africa

Coombes, Paul, and Watson. (2000). Three Surveys on Corporate Governance. www.clsa.com

Chandra, A (2003). "Prinsip-Prinsip dalam Merancang Kebijakan Good Governance dalam suatu Organisasi”. Usahawan, No.09.TH.XXXII. September 2003. 
SIIERGH Vol. 10 No. 2, JUNI 2008: 121 - 140

Clarke, A.D. (2006). SMEs and Corporate Governancee: Politics, Resources and TrickleDown Effects. University of Queensland

Daniri. (2008). "Meraih Kebangkitan Melalui Governance”, Bisnis Indonesia, Senin 19 mei 2008

Djatmiko, Harmanto, E. (2001). "Saatnya Menjadi Perusahaan Terpercaya", SWA, Oktober 2001.

Dirgantoro, Crown. (2002). Keunggulan Bersaing Melalui Proses Bisnis. Jakarta: Grasindo

FCGI Publication. (2006). What is Corporate Governance, www.fcgi.or.id

Hart, O. (1995). "Corporate Governance: Some Theory and Implications", The Economic Journal.

Hadiyati, dkk. (2005). Pendidikan dan Pelatihan Manajemen dan Administrasi Keuangan Untuk Pengusaha Kerajinan gerabah di Kasongan, Bantul, DIY. Laporan Pengabdian Masyarakat - Program Penerapan IPTEK DIKTI. Fakultas Ekonomi, Universitas Wangsa Manggala Yogyakarta.

Jewell, L.N. and Siegall. (1998). Psikologi Industri/Organisasi Modern, Jakarta: Arcan

Keasey, K.et.al. (1997). Introduction: The Corporate Governance Problem-Competing Diagnoses and Solutions.

Mayer, C. (1997). "Corporate Governance, Competition, and Performance". Journal of Law and Society

OECD. (1999). OECD Principles of Corporate Governance, the Organization for Economic Co-operation and Development. www.oecd.org/daf/governance/principles.htm

Pambudi, Teguh S. (2001). "Barisan Perusahaan Terpecaya”, SWA

Salim, E. (2000). Membangun Good Corporate Governance, www.transparansi.or.id

Syakhroza, A. (2003). "Teori Corporate Governance". Usahawan, No.08.TH.XXXII, Agustus 2003.

, (2002). "Mekanisme Pengendalian Internal dalam Melakukan Assesment terhadap Pelaksanaan Good Corporate Governance". Usahawan, No.08.TH.XXXI, Agustus 2002.

Sutawinangun, N (2004). Pelaksanaan GCG Pada UKM. www.fegi.or.id.

Tan, Wee Liang. The Impact of Corporate Governance on Value Creation in Entrepreneurial Firms. Singapore Management University. www.research.smu.edu.sg/faculty/edge.htm.2007

, et.al. (1997). The Impact of Corporate Governance on Corporate Entrepreneurship

Utama, Sidharta. (2005). "Praktek Corporate Governance dan Penciptaan Nilai Perusahaan di BEJ", Usahawan, Agustus 2005. 